\title{
Design Inverter SPWM Tow Frequency Based Soil Moisture Sensor Using Arduino
}

\author{
Antonius Rajagukguk* \\ Dept. Of Electrical Engineering, Faculty of Engineering \\ University of Riau \\ Pekanbaru, Indonesia \\ antonius.rajagukguk@lecturer.unri.ac.id
}

\author{
Riski Kurniawan \\ Dept. Of Electrical Engineering, Faculty of Engineering \\ University of Riau \\ Pekanbaru, Indonesia \\ riski.kurniawan@student.unri.ac.id
}

*corresponding author: Antonius Rajagukguk, antonius.rajagukguk@lecturer.unri.ac.id

\begin{abstract}
Inverters on induction motor control are widely used both in industry, transportation, household, and agriculture. This inverter is designed to convert Direct Current electricity into Alternating Current electricity. In this study, the inverter is designed using the Sinusoidal Pulse Width Modulation (SPWM) switching method and is able to produce pure sine waves of two frequencies of $50 \mathrm{~Hz}$ and $25 \mathrm{~Hz}$ with input control based on the reading of the soil moisture sensor. The purpose of this research is to apply to the controller of automatic watering plants. This system uses Arduino Uno as a SPWM signal generator and processes the reading of the soil moisture sensor and controls the LC filter. Based on the test results of the inverter control system, it is obtained an output voltage of 200 volts with a measured frequency of $48.83 \mathrm{~Hz}$ and $24.61 \mathrm{~Hz}$ with an input voltage of 12 Volt DC. The inverter system when loaded with single phase induction motors obtained efficiency at a frequency of $50 \mathrm{~Hz}$ by $36 \%$ and at a frequency of $25 \mathrm{~Hz}$ obtained by $70 \%$. Thus, it can be concluded that this single-phase inverter can be used for applications in single phase induction motor speed control.
\end{abstract}

Keywords-SPWM, h-bridge inverter, soil moisture sensor, low pass filter, Arduino

\section{INTRODUCTION}

The development of technology in the modern era is very rapid, this has an impact on some human tasks installed by electric machines, one of which is an electric engine with an induction motor type, this type of motor has advantages including easier maintenance, more reliability, relatively cheap price, and has efficiency which is high [1]. In addition, the motor speed can be controlled easily, from minimum speed to maximum speed, by the frequency of the input voltage. [1-2].

In a study entitled "Fuzzy Logic Method in the Concept of Water Irrigation with an Arduino Microcontroller" the prototype is designed to be able to control the speed of a DC motor type water pump motor, which works if the soil conditions are dry, the motor rotates very fast, if the ground is in moderate humidity it reduces the speed. motor, and if the ground is wet, the motor rotation will stop [3-4].
For system generate renewable energy from PV and Wind, inverters are often found by switching with the Pulse-width modulation (PWM) switching method. Most of the commercially available UPS are square wave inverters or quasi sine wave inverters which have a high harmonic content [5-9]. Inverter technology is one of the devices used for speed control and induction motor starting [10]. Switching techniques have continued to develop until now, one of the switching techniques offered to reduce high harmonic levels is Sinusoidal Pulse Width Modulation (SPWM), switching with the SPWM method has a characteristic with the pulse duty cycle increasing gradually and then decreasing gradually in the pulse which forms a sine wave pattern [10-15]. Inverter or quasi sine wave inverters which have high harmonic content [16-19].

In the current plant watering system, it is starting to use a better system that utilizes existing technology, one of which is an automatic plant watering tool using an AC motor type. This tool has another problem, namely the current type of induction motor AC motor cannot be regulated, therefore an automatic AC motor speed control system with a soil moisture sensor is needed as the main input. One way to adjust the speed of a single-phase induction motor is to use a variable frequency inverter, using the SPWM method, in dry soil moisture conditions the inverter produces a nominal motor frequency of $50 \mathrm{~Hz}$, then the motor speed is very fast, in moderate humidity or humid conditions. the inverter reduces the frequency by half of its nominal value, which is $25 \mathrm{~Hz}$, then the motor speed will decrease (slow), and in wet soil conditions the inverter does not operate (standby mode).

\section{Methodology}

This inverter is specially designed to be able to control the speed of a water pump motor type single-phase induction motor with a capacity of 280-Watt with a nominal frequency of $50 \mathrm{~Hz}$. Motor rotation speed based on soil moisture content in plants. The system block diagram of the system in general can be seen in the image below: 


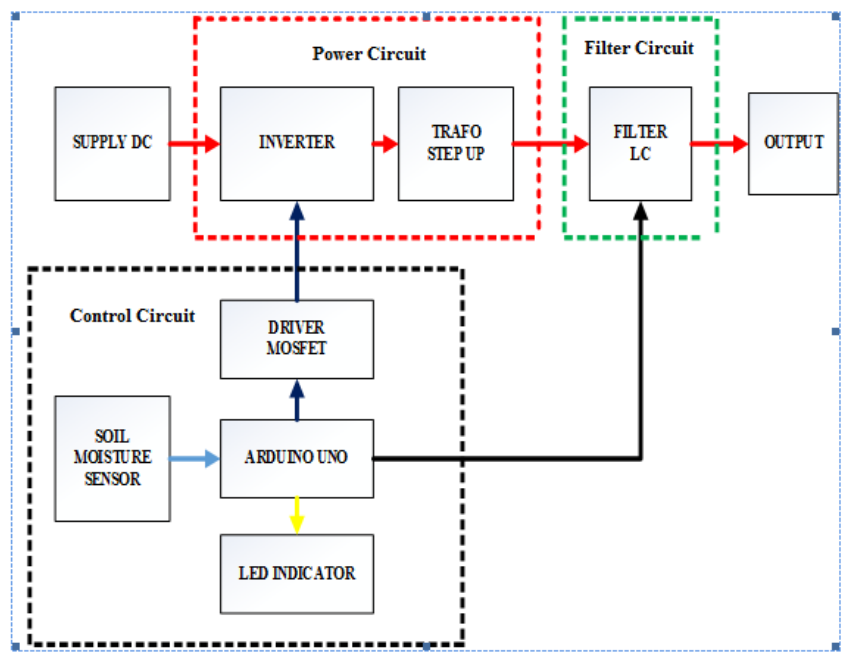

Fig. 1. Inverter Control System Block Diagram

TABLE 1 INVERTER DESIGN SPECIFICATIONS

\begin{tabular}{|c|c|}
\hline Specification & Information \\
\hline Power & 300 Watt \\
\hline Dry Frequency & $50 \mathrm{~Hz}$ \\
\hline Humidity Frequency & $25 \mathrm{~Hz}$ \\
\hline V input & $12 \mathrm{~V} \mathrm{DC}$ \\
\hline V output & $220 \mathrm{~V} \mathrm{AC}$ \\
\hline Output Wave Form & Sine Wave \\
\hline
\end{tabular}

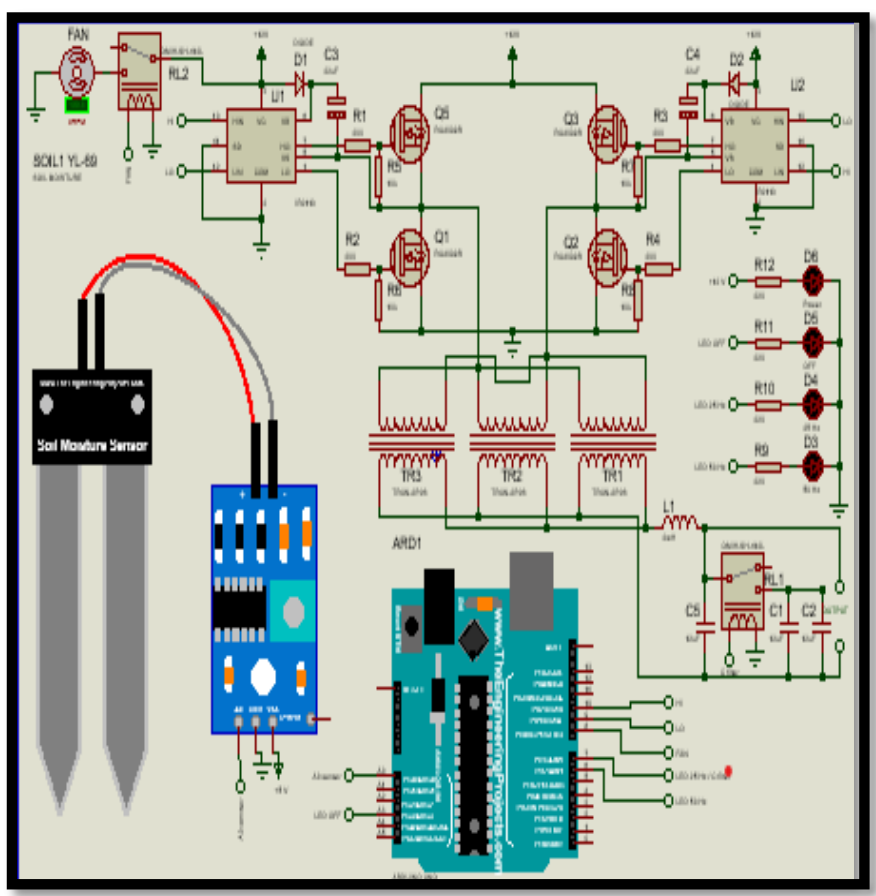

Fig. 2. Inverter Control System Circuit

The algorithm of the inverter control system performance is designed as illustrated in the system flowchart shown in Figure 3.

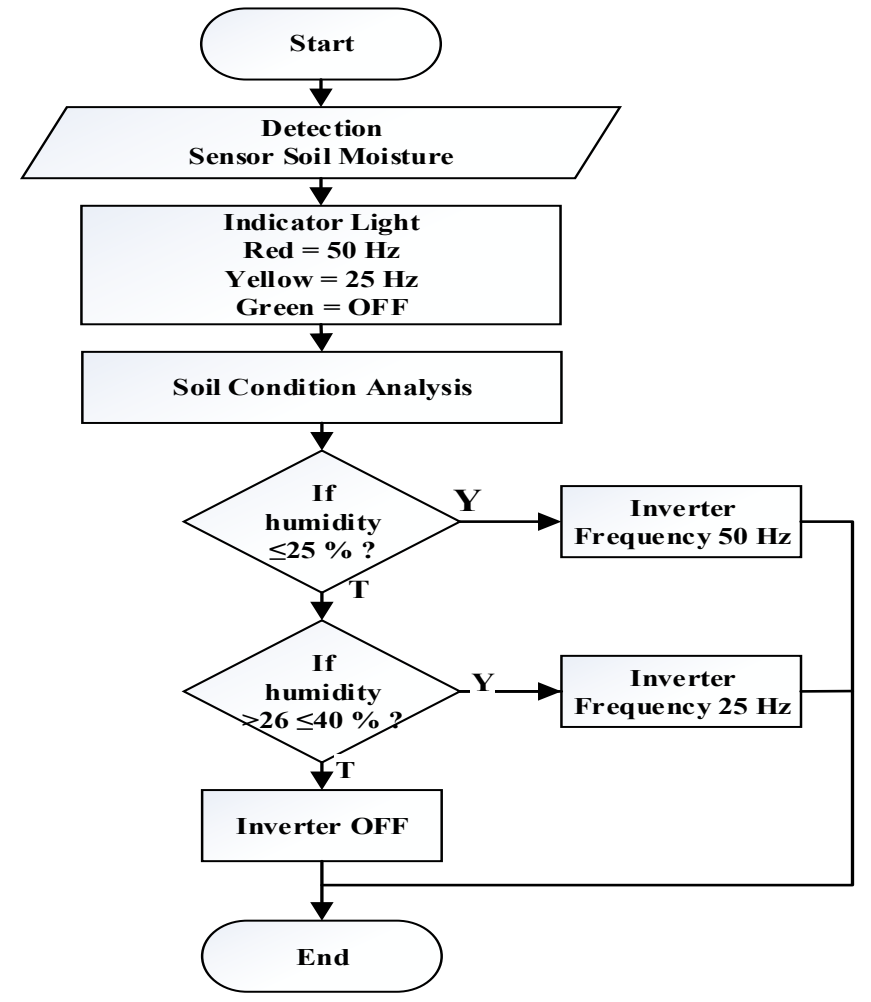

Fig. 3. Inverter Control Tool Performance

\section{RESUlt AND DISCUSSION}

\section{A. Soil Moisture Sensor Testing}

In this section, testing of the soil moisture sensor is carried out by testing several soil samples, to determine the moisture content of the soil samples tested. The soil samples used in this test consisted of four samples, namely, burnt soil, sand soil, peat soil, and yellow soil. The following are some of the soil samples to be tested which are shown in Figure 4.

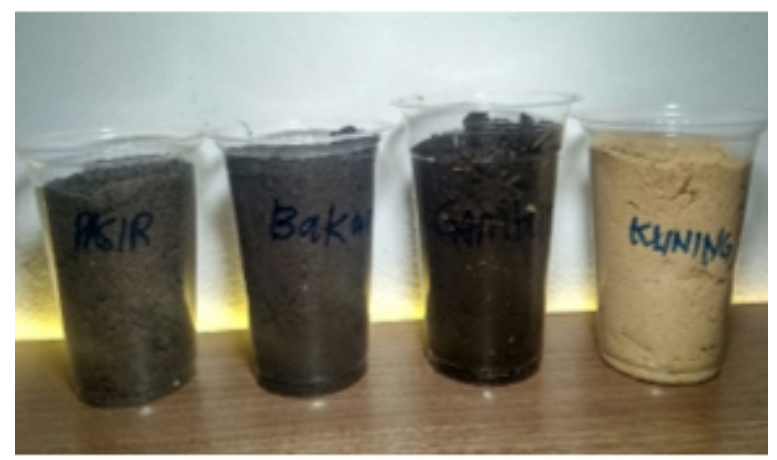

Fig. 4. Soil Samples to be Tested

The following are the results of testing the soil moisture sensor in dry soil conditions, which can be seen in Table. 
TABle II SoIl Moisture SENSOR Testing In DRy Conditions

\begin{tabular}{|c|c|c|c|}
\hline Type of soil & Moisture (\%) & $\begin{array}{c}\text { Indicator } \\
\text { Light }\end{array}$ & Information \\
\hline Yellow Soil & 1,56 & Red & Dry soil \\
\hline Peat soil & 18,38 & Red & Dry soil \\
\hline Burnt soil & 12,41 & Red & Dry soil \\
\hline Sandy soil & 9,29 & Red & Dry soil \\
\hline
\end{tabular}

TABle III SOIL MoISTURE SENSOR TESTING IN HUMID CONDITIONS

\begin{tabular}{|c|c|c|c|}
\hline Type of soil & Moisture (\%) & $\begin{array}{c}\text { Indicator } \\
\text { Light }\end{array}$ & Information \\
\hline Yellow soil & 35,09 & Yellow & Moist Soil \\
\hline Peat soil & 39,10 & Yellow & Moist Soil \\
\hline Burnt soil & 37,34 & Yellow & Moist Soil \\
\hline Sandy soil & 29,81 & Yellow & Moist Soil \\
\hline
\end{tabular}

TABLE IV SOIL Moisture SENSOR TESTING IN WET CONDITIONS

\begin{tabular}{|c|c|c|c|}
\hline & Moisture (\%) & $\begin{array}{c}\text { Indicator } \\
\text { Light }\end{array}$ & Information \\
\hline Yellow soil & 41,25 & Green & Wet Soil \\
\hline Peat soil & 68,43 & Green & Wet Soil \\
\hline Burnt soil & 66,86 & Green & Wet Soil \\
\hline Sandy soil & 58,46 & Green & Wet Soil \\
\hline
\end{tabular}

\section{B. $\quad$ Testing Sinusoidal Pulse Width Modulation (SPWM)}

The output signal from the microcontroller that has been programmed using the SPWM digital method with the Look Up Table Array method, the signal can be seen in the following figure.5.

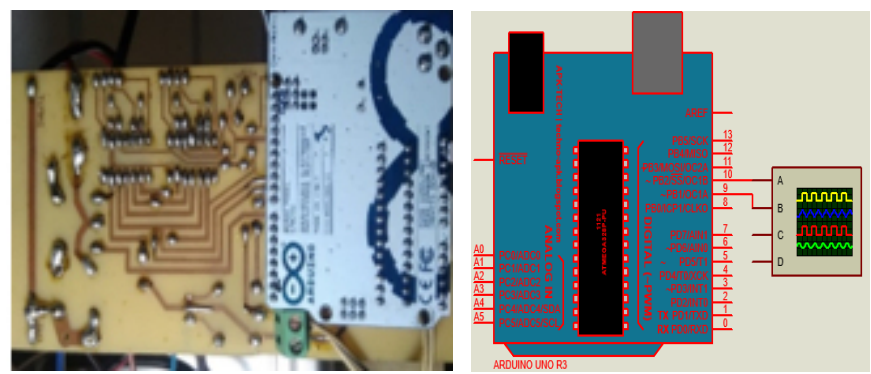

Fig.5 Arduino Uno SPWM Signal Testing

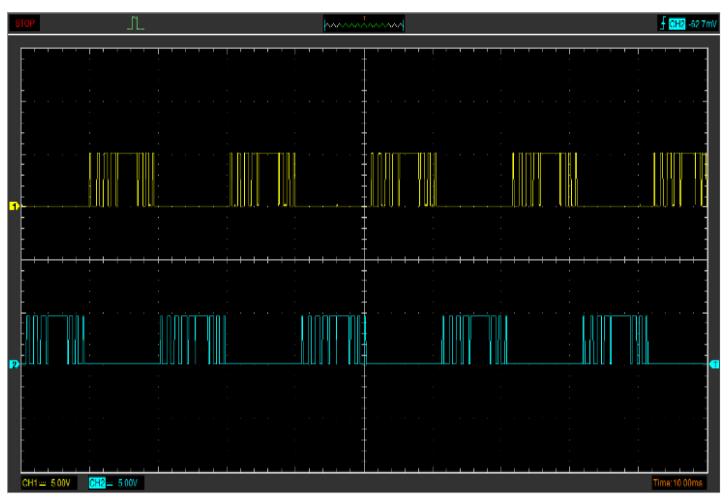

Fig. 6 The results of testing the SPWM $50 \mathrm{~Hz}$ signal with Arduino
Based on the measurement results in Figure 6 that the wave is in accordance with the initial design, and it appears that the two yellow waves are positive cycle switching waves, while the blue wave is the negative cycle switching wave, the two signals appear alternately.

\section{Testing The MOSFET Driver}

In this section, the MOSFET driver circuit is tested which is an advanced test on the Arduino SPWM wave. In this test, the $50 \mathrm{~Hz}$ frequency SPWM wave generated by Arduino is connected to the MOSFET driver IC 2110. The MOSFET driver prototype circuit is shown in Figure.7

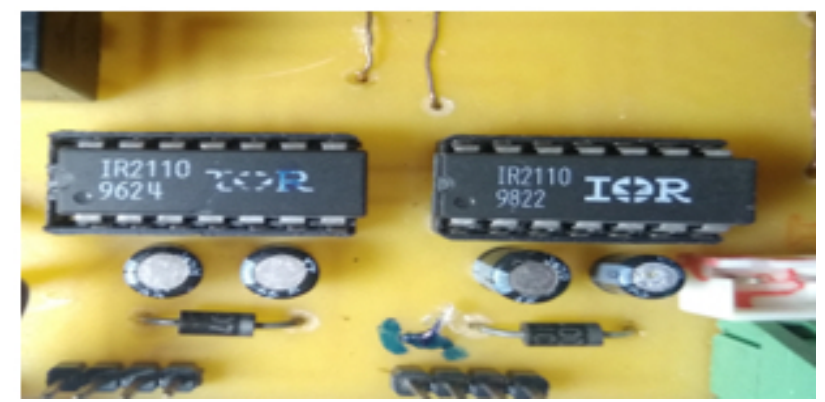

Fig.7 Measurement of SPWM Wave Output IC IR2110 prototype

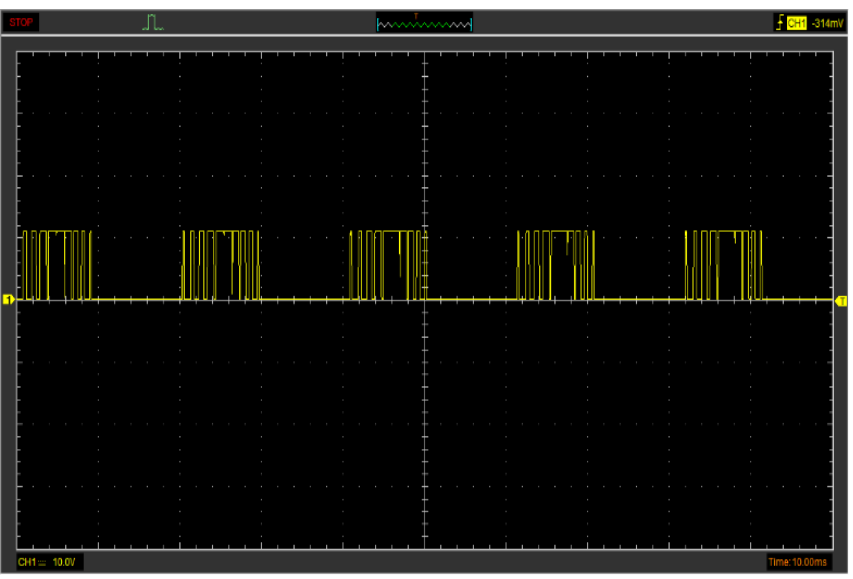

Fig.8 Measurement Results of the IR2110 MOSFET Driver Output Wave

\section{D. $\quad$ Testing Inverter in Wet Soil Condition}

At this stage, inverter testing is carried out by plugging the soil moisture sensor probe into the wet soil. In accordance with its function, namely, regulating watering the plants by maintaining the water content in the soil according to the water needs of the plants. For wet soil conditions, the plants have met their water needs. Therefore, it is not necessary to water the plants.

\section{E. $\quad$ Testing Inverter In Moist Soil Condition}

At this stage, inverter testing is carried out by conditioning the sensor area with water until it reaches a humid condition, so that the inverter control system generates a $25 \mathrm{~Hz}$ SPWM signal. The following is the measurement result of the inverter, before it is connected to the water pump motor. 


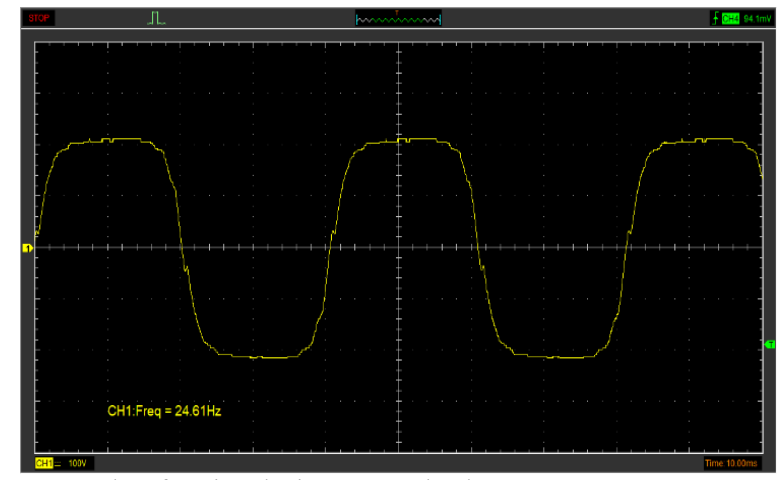

Fig. 9. Results of testing the inverter no load

Based on the test results in Figure. 9 It can be observed that the output waveform of the inverter terminal is almost sineshaped with a frequency of $24.61 \mathrm{~Hz}$. Furthermore, testing with an inverter connected to the water pump motor. Based on the test results, the prototype inverter output wave is shown in Figure 10.

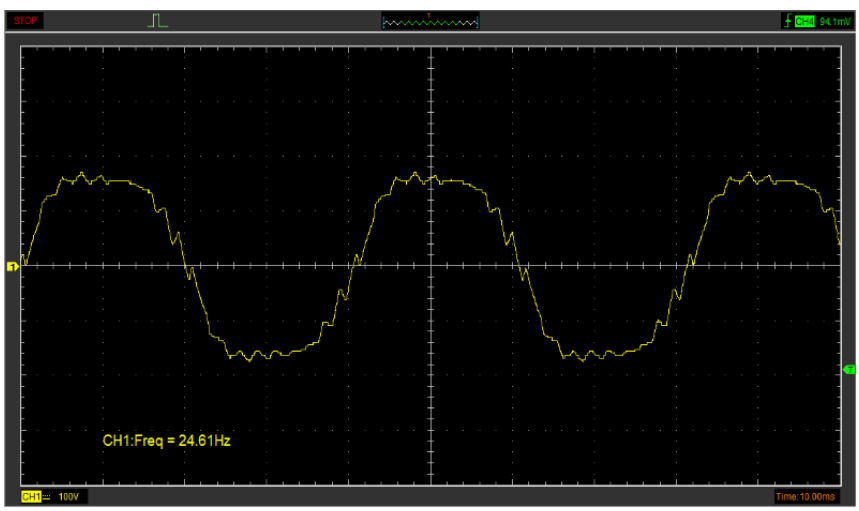

Fig. 10. Inverter Testing with Pump Motor Load

Based on the test results in Figure 10. It can be observed that the output wave of the inverter terminal after being connected to a motor load with a frequency of $24.61 \mathrm{~Hz}$ experiences distorted harmonic waves due to the effect of single-phase induction motor loading, this results in the inverter output wave being not pure sinusoidal but has ripples.

\section{F. $\quad$ Testing Inverter on Dry Soil Condition}

At this stage, inverter testing is carried out by conditioning the soil sample to a percentage of dry soil by evaporating the soil sample, until it reaches the soil condition in a dry state, so that the soil moisture sensor informs the microcontroller to generate a $50 \mathrm{~Hz}$ SPWM signal. The following is the measurement result of the inverter output wave when the water pump motor is not loaded.

Based on the test results in Figure 11. It can be observed that the output waveform of the inverter terminal is multilevel sine with a frequency of $48.83 \mathrm{~Hz}$. Furthermore, the measurement of the inverter wave when subjected to single-phase induction motor loading shows the wave result as shown in Figure 12.

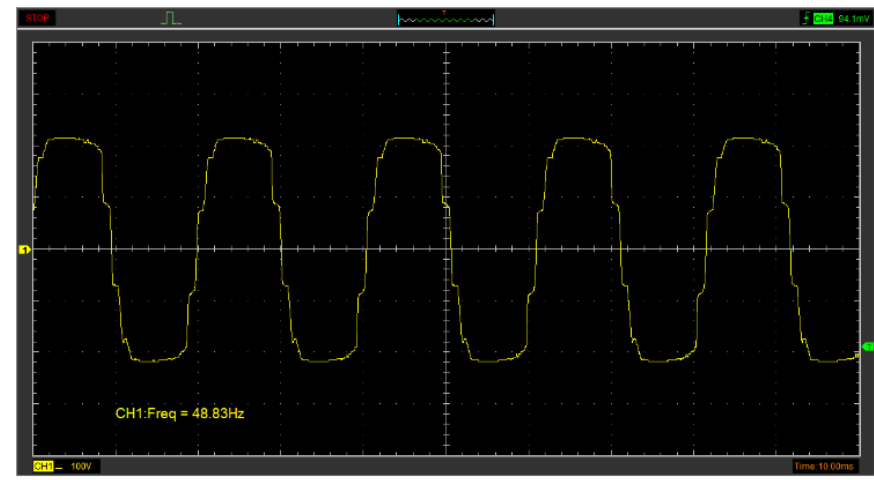

Fig. 11. Results of testing the inverter no load

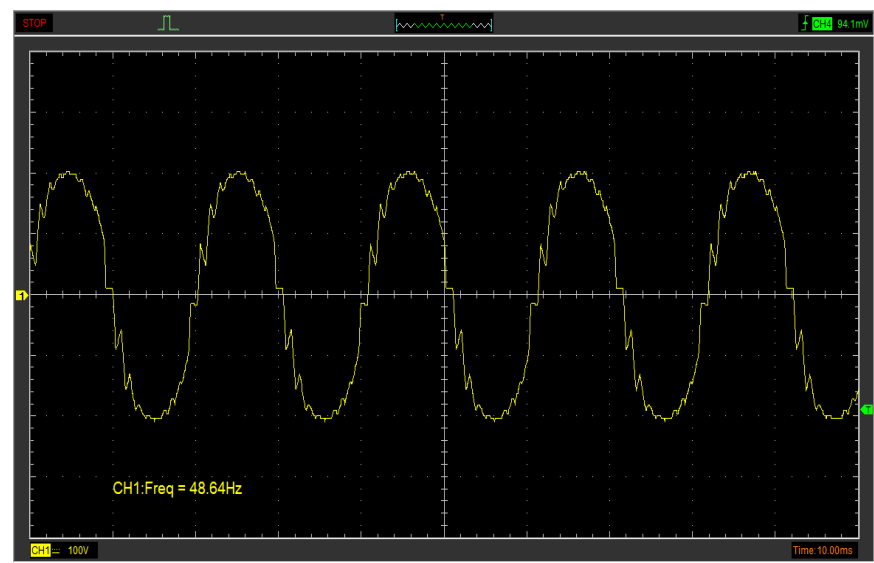

Fig. 12. Inverter Testing with Pump Motor Load

Based on the test results in Figure 12. It can be observed that the output wave with an inverter frequency of $48.64 \mathrm{~Hz}$, it can be seen that after being connected to the motor load, it experiences a slightly distorted harmonic wave, the effect of motor loading makes the inverter output wave slightly defective.

\section{G. $\quad$ Testing Inverter Power Efficiency}

This test aims to determine the power efficiency of the inverter control system prototype that has been designed, by conditioning the inverter in three soil conditions, namely, in dry, humid, and wet conditions. The following are the results of the measuring instrument readings shown in Table 5.

TABLE V INDUCTION MOTOR LOADED INVERTER EFFICIENCY

\begin{tabular}{|l|c|c|c|}
\hline \multirow{2}{*}{} & \multicolumn{3}{|c|}{ Soil Conditions } \\
\cline { 2 - 4 } & dry & moist & wet \\
\hline Vi(V) & 12,29 & 12,14 & 12 \\
\hline Ii(A) & 13,3 & 20,5 & 0 \\
\hline Vo(V) & 163 & 137 & 0 \\
\hline Io(A) & 0,4 & 1,4 & 0 \\
\hline $\cos$ Phi & 0,92 & 0,9 & 0 \\
\hline Pin (W) & 163,4 & 248,8 & 0 \\
\hline Pout(W) & 60 & 172,6 & 0 \\
\hline Eff (\%) & 36 & 70 & 0 \\
\hline
\end{tabular}




\section{H. Validation of Soil Moisture Sensor}

Soil moisture sensor validation was carried out by comparing the YL-69 sensor reading value obtained from serial monitors with readings of soil meters on the market, as shown in Figure 13.

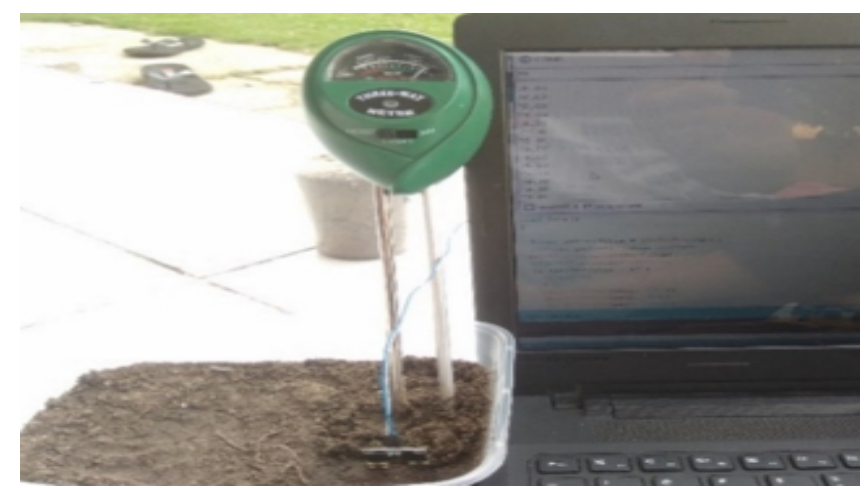

Fig. 13 Validation of YL-69 Soil Moisture Sensor with Soil Meter

Soil moisture sensor validation has been carried out 3 times on three samples of dry, moist, and wet soil. The following are the measurement results shown in Table 6.

TABle VI Results of MeAsurement SoIL Moisture Moist Meter AND SENSOR YL-69

\begin{tabular}{|c|c|c|c|}
\hline $\begin{array}{c}\text { Soil } \\
\text { Conditions }\end{array}$ & $\begin{array}{c}\text { Moist } \\
\text { Meter }\end{array}$ & $\begin{array}{c}\text { Sensor Value YL- } \\
69\end{array}$ & Difference \\
\hline \multirow{4}{*}{ Dry } & $10 \%$ & $11,24 \%$ & $1,24 \%$ \\
\cline { 2 - 4 } & $20 \%$ & $22,58 \%$ & $2,58 \%$ \\
\cline { 2 - 4 } & $23 \%$ & $23,17 \%$ & $0,17 \%$ \\
\hline \multirow{4}{*}{ Moist } & $29 \%$ & $34,02 \%$ & $5,02 \%$ \\
\cline { 2 - 4 } & $35 \%$ & $37,73 \%$ & $2,73 \%$ \\
\cline { 2 - 4 } & $39 \%$ & $40,37 \%$ & $1,37 \%$ \\
\hline \multirow{4}{*}{ Wet } & $53 \%$ & $55,91 \%$ & $2,91 \%$ \\
\cline { 2 - 4 } & $90 \%$ & $80,94 \%$ & $0,94 \%$ \\
\cline { 2 - 4 } & $92 \%$ & $88,56 \%$ & $3,44 \%$ \\
\hline
\end{tabular}

Based on the test results obtained some data that can be analyzed, the measurement results of the YL-69 sensor with sensors on the market have a difference of $0-5 \%$, this happens because the sensor construction is different from the calibration tool, causing differences in the reading of the soil moisture value.

\section{I. $\quad$ Validate the inverter output frequency}

At this stage, the output frequency validation of the inverter control system prototype that has been made with the inverter design is simulated using the Proteus Pro software. The following is a comparison curve of the inverter output frequency which is shown in Figure 14. Based on the curve in Figure 14 shows the difference between the simulation results and the prototype measurement results, in the case of dry soil an error of $2.34 \%$ is obtained, while in the case of moist soil it shows an error of $1.65 \%$. This difference is caused due to the mismatch of the components used based on the calculation results, and also due to the tolerance factor to the accuracy of the measuring instruments used.

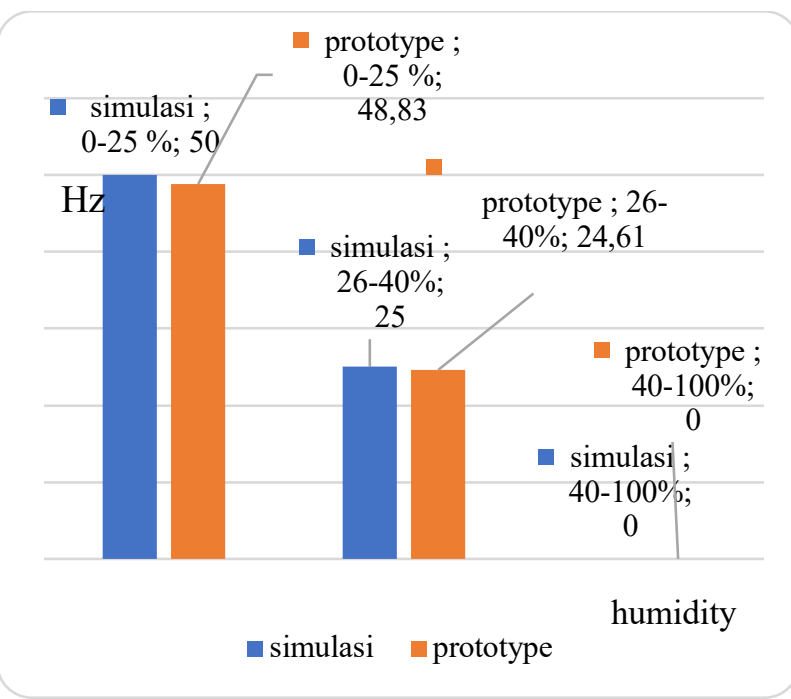

Fig. 14. Inverter Frequency Validation

\section{CONCLUSION}

Based on the test results, the inverter control system prototype is able to produce a sine wave with a frequency according to the proportion of soil content, in dry soil conditions with a proportion of $25 \%$, the inverter produces a frequency of $48.83 \mathrm{~Hz}$, for moist soil conditions with a proportion of $25-40 \%$, inverter produces a frequency of $24.61 \mathrm{~Hz}$ and on wet soil with a proportion of more than $40 \%$ the inverter is in standby mode. The inverter voltage is capable of producing 200 volts at the same frequency, after the water pump motor, the inverter experiences a voltage drop, so that the inverter voltage in dry soil conditions is 163 volts, while in moist soil conditions the voltage is 137 volts.

\section{ACKNOWLEDGMENT}

The authors gratefully thanks to God and would like to convey a great appreciation to Riau University, Indonesia for supporting this research.

\section{REFERENCES}

[1] Yusuf, M., Prasetia, V, Riyanto, S. D., \& Rafiq, A. A. "Desain Simulasi Sistem Pengaturan Kecepatan Motor Induksi Tiga Fase dengan Switching Space Vector Pulse Width Modulation", Jurnal Ecotipe (Electronic,Control,Telecommunication,Information, and Power Engineering), 6(1), 24-31, 2019.

[2] Citarsa, I. B. F., Satiawan, I. N. W, Wiryajati, I. K. "Pengaruh teknik modulasi PWM pada keluaran inverter tiga fase untuk pengaturan kecepatan variabel motor induksi", DIELEKTRIKA, 2(1), 32-39, 2018.

[3] Pradana, R., \& Irawati, R. "Metode Fuzzy Logic dalam Konsep Irigasi Air dengan Microcontroller Arduino". Telematika MKOM, 8(2), 107-113, 2017.

[4] Hartono, B. P, \& Nurcahyo, E. "Analisis Hemat Energi Pada Inverter Sebagai Pengatur Kecepatan Motor Induksi 3 Fase.” Elektrika: Jurnal Teknik Elektro, 8-16, 6(1), 24-31, 2019.

[5] Kjær, Søren Bækhøj, "Design and Control of an Inverter for Photovoltaic Applications", Denmark Institute of Energy Technology, Aalborg Universitet, 2005. 
[6] Kwang, Tan Kheng; Masri, Syafrudin Bin, "Grid tie photovoltaic inverter for residential application", Modern Applied Science, 5(4), 2011.

[7] Rajagukguk, Antonius; Aritonang, Maryani, " Optimization of PV Power Capacity of $10 \mathrm{KWp}$ Capacity Based on P\&O Algorithm and Boost Converter", International Journal of Electrical, Energy and Power System Engineering, 57-64, 2020.

[8] Antonius R, C.W. Priananda, D. C. Riawan, dan M. Ashari, "Prototype of power optimization based on converter topologies reconfiguration using PV string smart clustering method for static miniature photovoltaic Farm under partially shaded condition", International Review of Automatic Control (I.RE.A.CO.), Vol.10, No. 4, July, 2017.

[9] Antonius R, Dedet Candra Riawan, Mochamad Ashari "Performance Characteristics of Miniature Photovoltaic Farm Under Dynamic Partial Shading", Indonesian Journal of Electrical Engineering and Computer Science Vol. 11, No. 1, pp. 400 408, July, 2018.

[10] Muttaqin, S., Setiawan, I, and Facta, M. "Desain dan Implementasi Voltage-Source Inverter (VSI) Tiga Fase Sinusoidal Pulse-Width Modulation (SPWM) dengan Dspic30f4011", Transmisi, 18(4), 152160, 2016.

[11] Azmi, Khairul, Sara, Ira Devi, Syahrizal, Syahrizal, "Desain dan Analisis Inverter Satu Fasa dengan Menggunakan Metode SPWM Berbasis Arduino", Jurnal Karya Ilmiah T. Elektro, 2(4), 2017.

[12] Bhattacharjee, T, Jamil, M., \& Jana, A. "Design of SPWM based three phase inverter model", Technologies for Smart-City Energy Security and Power (ICSESP), pp. 1-6, 2018.

[13] Wardana, M. K., Fadlika, I, \& Fahmi, A. "Rancang Bangun Inverter Satu Fasa SPWM Dengan Output Tegangan dan Frekuensi Variabel", TEKNO Jurnal Teknologi, Elektro, dan Kejuruan, pp. 116, 2018.

[14] Asrul, J, Yefriadi, Y, Ismail, I, Muchtara, E., Rizky, M, \& Hidayat, $\mathrm{V}$, "Kontrol Motor Induksi 1 Fase Menggunakan Raspberry Pi”, Jurnal Teknik Elektro, 9(1), 6-10.

[15] Biswas, S. P, Hosain, M. K., Sheikh, M. R. I., Kibria, M. F., Hasan, F, \& Haque, M. Y. Y. U. "A Noble Approach for Generating Real Time Firing Pulse for Inverter Using Arduino and MATLAB/Simulink", 4th International Conference on Electrical Engineering and Information \& Communication Technology (iCEEiCT), pp. 662-665, 2018.

[16] Setyo Adi Purwanto, Setyo, Renny Rakhmawati, Renny, Hendik Eko Hs, Hendik, "Penggunaan Inverter sebagai Filter Daya Aktif Paralel untuk Kompensasi Harmonisa Akibat Beban Non Linier", EEPIS Final Project, 2011.

[17] Doucet, J, Eggleston, D, \& Shaw, J. "DC/AC Pure Sine Wave Inverter", PFC Worcester Polytechnic Institute, 2007.

[18] Ismiyadinata, J, Yuliansyah, H, Aziz, M. R. K, \& Rohman, A. S, "Desain dan Implementasi Inverter Satu Fase 400Watt dengan Metode Switching High Frequency", Journal of Science and Applicative Technology, 3(1), 9-16, 2019.

[19] Sayekti, I, "Rancang Bangun Modul Inverter Gelombang Sinus Menggunakan LPF Orde Dua Sebagai Pengubah Gelombang Kotak Menjadi Sinus", Orbith, Majalah Ilmiah Pengembangan Rekayasa dan Sosial, 11(2), 2015. 